\title{
The Idea of the Perfect Person in the Views of Middle Eastern Thinkers
}

\author{
Agzamkhodzhaeva Shakhnoza Saidmatlabovna \\ Head of the Department of Social Sciences of the Tashkent Institute of Textile \\ and Light Industry, Candidate of Economic Sciences, Associate Professor
}

\begin{abstract}
In the works of medieval oriental thinkers Abu Nasr Farobi, Alisher Navoi, Mahmud Asad Joshon, Boyazid Bistomi, Ibn al-Arabi, Aziziddin Muhammad Nasafi, Abdukadir Jili, Abdulkadir Gilloni, Hazrat Alikulov, Ibrahdandura Ibrahdultansky People have dreamed for centuries to raise the perfect person. Representations and ideas about him in different periods were interpreted in different ways. The evolution and improvement of the idea of perfection depended on the nature of the system, the level of production, the method of government, the development of science and culture.
\end{abstract}

Keywords: perfect man, heritage, fiction, nation, skillful organization, deep knowledge, morality, etiquette, high meaning, lust, truth, divine science.

\section{INTRODUCTION.}

The question of the ideal person has been of interest to humanity since ancient times, and information about him has been preserved in oral and written sources, works on mythology, the socio-philosophical heritage of thinkers and fiction [36]. From this point of view, one can agree with the opinion of the famous mystic Mahmoud Asad Joshan. He asked, "Will the behavior change?" "It's only through education that this will change," he said.

The idea of an ideal man has always been the noble dream of our people, an integral part of the nation's spirituality. In the sacred book of Zoroastrianism, Avesto, honest work is interpreted as the main criterion of perfection. The idea of the ideal man was nurtured by Islamic philosophy and took on a broader meaning. The ideas of such thinkers as Ibn Sina, Beruni, Farobi, Navoi about the upbringing of a perfect person are related to the search for new spiritual opportunities for the development of society. Promoting his ideas about the townspeople, Farobi Fozil considered the spiritual maturity of an individual to be the main condition for building a just society [3, p. 45]. 
Historically, the activities of great people have acquired high importance not only because of their skillful organization and deep knowledge, but also because of their morals and manners. Politeness means respect not only for others, but also for yourself. In particular, according to our national traditions, the perfection of a person is reflected, first of all, in his moral maturity, in his desire to deeply study and enrich the heritage of ancestors, to show respect for everyone, big and small. Not everyone can independently determine the level of perfection. Perfection is better known to others than to every human being.

\section{MAIN BODY.}

The ideal man is one who is completely free from bondage, dumbness, and dependence. Because if a person follows someone like a slave, it means that he has not achieved anything socially. The ideal man does not blindly follow those who spread harmful ideas alien to the interests of his country and people, he is alert and active [15, p.65].

From time immemorial, our people have wonderful traditions and teachings, including love for the Motherland, the holiness of the Motherland and Motherland as a place of worship, not a lie, not a betrayal of someone's rights, respect for the great and the small. They are rooted in the life, lifestyle, spirituality and mentality of our people. In this sense, it is clear that these requirements of our ancestors mentioned the most important qualities for society and a person. It is said that a flowing river flows, and the descendants of great ancestors who have strong faith grow up to be worthy children who embody these qualities. Therefore, our Motherland is trying to educate the younger generation.

The idea of an ideal person by its very nature has a national, universal and humanistic meaning. Every society strives to raise a mature, versatile generation that possesses all positive and noble qualities. Consequently, the question of the ideal man is rooted in the distant past. In the sacred book of Zoroastrianism, Avesto, the idea of the perfect man is at the forefront of Buddhism and Islamic teachings. For example, Zoroastrianism is based on three basic moral principles: "Good thought, kind word, good deed." A person who follows these three rules is considered mature.

The idea of the ideal man found a vivid expression, especially in the philosophy of Central Asia in the early Middle Ages. 
The great philosopher of the Renaissance, thinker Abu Nasr al-Farabi (873-950), who received the title of "second teacher", his ideas about the perfect man were reflected in his socio-political and moral views.

Farobi is a great humanist whose work focuses on human issues. The concepts of his noble community, the state and its leader, virtue, perfection, happiness are inextricably linked with the ideal man. According to the scientist, from birth, a person strives to acquire qualities, maturity and perfection. "Every person," says the scientist, "is not perfect from the very beginning, but strives for perfection step by step with an innate instinct." The perception of everything leads a person to perfection and pleasure. True spiritual perfection of a person is formed through the first cognition of the Truth, and this is simultaneously enlightenment, happiness and pleasure "[2, p. 14].

According to Farobi, humanity is the highest virtue in achieving perfection and happiness. His works are based on human thoughts, dreams and hopes. According to him, in order to be perfect, humanity must communicate with others, receive help from them and help others.

In mystical philosophy, at the heart of the problem of the ideal person is the doctrine of unity. The unity of God, being and man, the union of man with God, the unity of ontological and epistemological issues are interpreted on the basis of the doctrine of existence.

As the great scientist and thinker Abu Nasr al-Farabi said: "Since the essence of humanity is the achievement of true happiness, if a person makes this goal his highest idea and desire and uses every opportunity in this way, he will achieve happiness." [3, p. 188]. Thus, it is aimed at uniting and uniting people, represents multifaceted political, social, legal, national and other interests and unites them into a single social and spiritual movement in the hands of national, national goals.

There are many symbols of perfection in our history: Alpomish is the ideal hero of our people, he is an artistic symbol of intelligence, intellect, physical maturity, courage and patriotism. The ideal for Hazrat Navoi is the image of Farhod. He is smart and physically mature. He embodied the principle of Farhod Naqshbandi "Dil ba yoru, give ba kor". In Oybek's novel "Navoi", Navoi is an ideal image. At the same time, he is a real historical person, an ideal man.

Today, the Motherland sets before the artists the task of creating new harmoniously developed people, the image of modern heroes who will be an example for young people. A free and prosperous Motherland, which is the highest goal of our 
independent Motherland, can only be built by mature people who have transformed a free and prosperous life into a harmonious noble idea of life.

Therefore, in the renewal of Uzbekistan, much attention is paid to the upbringing of a healthy generation, the formation of a free civic spirit, the development of mature people through a high level of spiritual and educational work. The expansion of the movement of the healthy generation in our country, the radical reform of the education system based on the national curriculum are also important steps towards the realization of this glorious goal.

Among the Sufis, Bayazid Bistami (died in 874), Ibn al-Arabi (1165-1240), Aziziddin Muhammad Nasafi (13th century), Abdukadir Jili (died in 1417), Abdulkadir Gilani (1077-1166) and others were biased. For the first time in their works, they analyzed the concept of "ideal man" from a mystical point of view.

Ibn al-Arabi and Abd al-Qadir al-Jili paid more attention to the human spirit and spiritual excellence. The famous 13th century mystic, Aziziddin Muhammad Nasafi, was concerned with the problem of the ideal man. Nasafi approached this issue from a theoretical and philosophical point of view in his works "Zubdatul haqik" ("Cream of Truth"), "The Ideal Man".

Nasaf's worldview is based on a specific person. When he talks about a person who has reached perfection, he means, first of all, self-knowledge and morality. He recognizes that a person's character, the acquisition of high qualities and his enlightenment are important signs of an ideal man [21].

The question of raising the ideal man is especially relevant in the current conditions of independence. This is due to the fact that during the period of transition from a dictatorial regime to a society based on market relations, this issue becomes more and more acute. The decline in the value of certain values in interpersonal relationships, the frequent appearance among young people of drug addiction, fraud, greed, selfishness, theft and other vices requires attention to the upbringing of a harmoniously developed generation. The issue of the ideal man is also given special attention in the works, speeches and speeches of the First President of the Republic of Uzbekistan Islam Karimov. The 1st President defines an ideal person as follows: "When we talk about an ideal person, we mean, first of all, educated, enlightened people who are very smart, able to think independently and whose behavior is an example for others. A conscious, knowledgeable person cannot be deceived with gossip. He weighs everything on the scales of reason and logic. The one who bases his thoughts and conclusions on logic becomes a mature person "'[18, p. 6]. 
The teachings of the perfect man in antiquity and the early Middle Ages reflected the aspirations and thoughts of the people. Hamida had to instill morality (morality worthy of praise), beautiful virtues and rules of conduct. Secondly, the disclosure of the characteristics of the perfect person by the Sufis became the spiritual basis for the works, views and ideas of later scientists and philosophers. Thirdly, the views of the great sages of the ancient and early Middle Ages on the perfect person, his valuable ideas on this matter greatly influenced the worldview of later thinkers, especially Navoi, and served as an important ideological source in the formation of moral thinking. views.

Rich artistic creativity, philosophical, socio-political, moral views of Hazrat Navoi, in particular his ideas about an ideal person, an ideal society, have always attracted the attention of literary critics, teachers and philosophers. Although Alisher Navoi's views on the ideal man were not the subject of special studies in the studies of the Soviet era, they were covered by N. Mallaev, E. Bertels, V. Zokhidov, IM Muminov, M. Khairullaev, Kh. Alikulov, M. Aripova [22 , 10, 16, 30, 25, 36, 33, 34, $8,9,39]$.

Analyzing the work of Alisher Navoi, in particular the epics included in the "Khamsa", N. Mallaev noted that Navoi "criticized religion and mysticism" and that they "were not the main, leading factor in the work of Navoi" [22].

The well-known Russian orientalist E. Bertels analyzes the work of Navoi, especially the content of his epics included in the "Khamsa", and notes their honesty, courage and courage [10].

According to Academician V. Zakhidov, who studied the work of Alisher Navoi, artistic symbols in the epics of Navoi improved in secular affairs, humanism, and the acquisition of excellent qualities [16, 30].

The studies of the philosopher-scientist M. Aripov reveal the essence of such issues as the worldview origins of Navoi humanism, the doctrine of man, the concept of unity-ul-wujud [9]. However, since the scientist did not set himself the goal of examining Navoi's views on the ideal man, he limited himself to a brief presentation of this issue.

In his study, Kh. Alikulov compares the socio-political views of Alisher Navoi with the views of Abdurahmon Jami, Hussein Voiz Kashifi and Jaloliddin Davoni on society and the state [8]. In our opinion, Navoi scientists and philosophers of the Soviet era had to deliberately bypass religious and mystical ideas in the work of Navoi, especially in his epics. This is due to the fact that in the 60-80s of the last 
century, Islam and mysticism were not approved by the dominant ideology, and their place in history could only be assessed negatively.

An in-depth and comprehensive study of the creative heritage of Alisher Navoi, a new approach to it began in the new Uzbekistan $[8,9,14,5]$. Among these approaches, an important role is played by the question of how to analyze the idea of an ideal man in the work of Navoi and what style to use to highlight it. In recent years, a number of articles on this topic have been published [17, 27, 13, 1, 11], which indicates that the study of the idea of an ideal man is extremely important today.

In recent years, a number of studies have been carried out on certain aspects of the literary heritage of Alisher Navoi, in which the research of Navoi scientists, especially N. Kamilov, I. Hakkul and others, is of scientific importance [24, 11, 20]. ...

It should be noted that the ideas of morality, rules of behavior, humanity and humanity, self-control, justice and enlightenment, love for nature and man, their respect, education in the philosophy of mysticism are effectively used in the work of Hazrat Navoi. These ideas are embedded in the thinker's gazelles and rubs, in epics, and prose. As I. Khakkul noted, "Navoi's approach to mysticism and the goal of this teaching were the approach and goal of the thinker-artist who was responsible for the fate of a person and nation, fought for the development of the country." [12, p. 27].

We support the idea that "Navoi did not intend to specifically deal with the theoretical and practical aspects of mysticism," as stated in the scientific literature. In this respect, we agree with the opinion of Sultan Murad Murad that, although he lived a mystical life, he could not be considered a true Sufi, like Hamadoni, Gijduvani, Yassavi and others. After all, Hazrat Navoi "did not sit as a sheikh in a khanak, did not gather murids around him, did not pass additional riyads, did not go into solitude and did not sit in a chilla" $[28$, p....

Navoi and his ideas about the ideal man are probably wrong to interpret only in the crust of mysticism. His worldview, the concept of the ideal person was also strongly influenced by the secular views of the thinkers of the early Middle Ages. Navoi was a great sage and humanist poet of the Renaissance.

You cannot imagine the great thinker, poet and mystic of the 15th century, friend of Alisher Navoi Abdurahmon Jami (1414-1492). Alisher Navoi, on the advice of Jami, believes in the Naqshbandi leech and considers Jami not only a friend, but also a teacher, a feast. Before writing the work, Navoi consulted with his colleague Jami and took into account his valuable opinions. 
Hussein Waz Kashifi (1440-1505) is one of the scholars who wrote special works on moral and educational issues during this period. He is engaged in scientific activities under the direct patronage and assistance of Hazrat Navoi. In addition, Khandamir's work Makorim ul-ahlak (Noble Behavior) was written, in which Alisher Navoi is described as a mature person, a perfect man, embodying all human qualities. The performance is permeated with Navoi's tolerance, humility and modesty, generosity, patronage of scientists, high intelligence, kindness, desire to improve the country, care for poets, scientists and scientists, justice and other humane qualities [35].

Another topical issue of the 15th century is its close connection with independence. Indeed, in Central Asia, which was first liberated from the Arab conquest, and then from the Mongols, science and culture flourished, and wide opportunities opened up for the development of free thought and intellect. "Farobi's ideas about a noble community, a perfect person, peoples living on the basis of mutual assistance, Jami, Navoi's ideas about a country of justice, endless humanity and high morality were born in such independence and, above all, mean independence" [34, p. 14], - said M. Khairullaev.

An ideal man is "on the one hand, an abstract concept of total spiritual strength, intelligence, a set of good qualities, and on the other hand, a person who strives for this peak and makes a certain career is also considered an ideal person" [20, p. 138].

Alisher Navoi created a whole doctrine about the ideal man. His prose and poetic works, ghazals, epics were included in "Khamsa", "Nasaim ul-muhabbat", "History of prophets and rulers", "Kholoti Sayyid Hasan Ardasher", "Mahbub ul-kulub", "Majlis un-nafois" "Lysone ut-tayre" and others reveal in detail the idea of what an ideal person should be and what qualities he should have.

The perfect human teaching of Navoi is based on love for nature, man and God. When he talked about prophets, saints, piru kamils, arif and Sufis, he wrote lovingly about the qualities of the saints in his gazelles and rubai. According to the mystic Ibrahim Hakkul, Navoi's views on perfection are based on four priorities: the beauty of morality, the purification of the soul, the power of the Spirit, and the maturity of thought.

The Thinker includes prophets, saints and sages, great prophets among perfect people. Such people always live in the grief of people, show kindness to others and help widows. Perfect beings are the best of people who have chosen the path of purification and truth for the rest of their lives. 
Alisher Navoi in his book "The History of Prophets and Rulers" focuses on the prophets who lived before Muhammad. He does not put one of the prophets above the other, but objectively illuminates their activities. He describes the life of the prophets, their way of life, the good deeds they did, their attitude towards citizens and their efforts to live in peace and tranquility, and considers them to be perfect people. But it should be noted that Navoi, like all Muslim oriental thinkers of the past, great sages, interpreted the Prophet Muhammad as the best of all previous prophets, a perfect, perfect person. Therefore, in many of his works, in particular, in his epics included in "Hamsa", "Munojat", "Lison ut-tair", "Siroju-1-Muslimiyn", "Nasaimul-muhabbat", "Nazmul-Javohir" and etc. There are many places where quality is praised. The great thinker says about the Prophet Muhammad: "And since he was the end of the Prophet, and then the door of prophecy was closed, every month the imperfect commanded perfection and the scientists of the Ummah to perfection in order to take the place of the former prophet and pave the way". [6, p. 14].

The Thinker interpreted the prophets, that is, the keepers after the prophets, as perfect people. The scientist dwells on the qualities of the saints, such as repentance, eating honest food, adhering to the teachings of the sect, humility, gentleness, generosity, patience, in particular, when he talks about honest food, he understands that the guardian is engaged in a profession and earns a living. Indeed, it is known from history that the great representatives of mysticism, the guardians, were engaged in a certain profession. According to Navoi, Haji Abdullah Ansari was a shoemaker, Sheikh Muhammad Saqqak was a master of knives, Sheikh Abu Hafz Khaddad was a blacksmith, Sheikh Abulabbas Omili was a butcher, Sheikh Abulabasan was a muezzin, Sheikh Banon Bakhilbakh was a wearer. embroiderer on fabric [6, 15].

In the epic of the great thinker "Farhod and Shirin", "Laili and Majnun", the interpretation of artistic symbols from the point of view of mystical teaching also plays an important role. In the epic, the love of Farhod and Shirin, Leyli and Majnun is figurative love, that is, Shirin intertwines love for Allah in the form of Leyli. It contains the idea that divine love cannot be achieved without appearances, and Truth cannot be achieved without the worldly.

According to Navoi, an ideal man is not an imaginary person, but a real person who embodies all external and internal knowledge, human qualities. Secondly, for Navoi, the prophet Muhammad is a great man who reached a higher level than other prophets. Thirdly, the fight against life's hardships, such as moral purity, self-control, oppression, injustice and injustice, lies at the heart of Farhad's humanity and serves as 
the basis for his formation as a perfect person. It has the effect of the Naqshbandi sect, futuvwat, that is, the flow of valor. Fourthly, in Soviet times, the love of two young people in the epics of Navoi was interpreted only from a secular, external point of view, although when analyzing the idea of an ideal man, it is necessary to shed light on its secular and divine, external and internal aspects.

Alisher Navoi's idea of an ideal person is reflected in the management of the state, in his vision of an ideal, perfect society, in the thoughts of a just king, in the attitude of the ruler to the people, in observance of religious and legal norms.

In his epics, included in "Hamsa", especially in "Saddi Iskandarii", "Sabai Kayar", "Farkhod and Shirin", the scientist brings people happiness, the development of the country, the well-being of the people. , free from oppression, injustice, violence and injustice, which is a perfect society and just, perfect in all respects the king.

The great thinker, reckoning the righteous king among the perfect, emphasizes that if he follows the path of justice, the country will prosper, people's lives will improve, and there will be prosperity and abundance. Alisher Navoi wants to see his friend Sultan Hussein Boykarod as a fair, patriotic, wise king described in his works. He always encourages him to do good deeds and live with the suffering of people. For example, Navoi told Hussein Boykaro: "Never let your heart ignore the memory of God and the hearts of Muslims. There is no place for indifference to the opinions of friends and the intrigues of enemies, and this work will not bring any results, except regret "[7, $p$.

In the Middle Ages, the prevailing idea was that the king was the caliph of God on earth. According to him, the king is a symbol of justice, which he must apply to the people of the world, and in his activities he must act only in accordance with the rules of justice and not deviate from them. British Islamic scholar E. Rosenthal, who conducted a study on this issue, said: "In Muslim countries, it is customary to assess the activities of the head of state from two different points of view. These are divinelegal and historical-political aspects. In addition, the heads of state, remembering that they are Muslims under any circumstances, believed in the supremacy of an ideal Islamic state in accordance with Sharia norms "[42, p. 6], confirms this opinion. Hazrat Navoi also agrees in his writings that the king is the keeper of people on earth, the representative of Allah on earth. In his book Mahbub ul-Kulub, the scientist says: "A just king is a blessing to the people, a cause of peace and prosperity for the country. Like the sun and spring rain, flowers will bloom from the black soil, and the heads of the country's inhabitants will be covered with gold and pearls "[5, p. 12]. 
The idea of the ideal man also plays a leading role in the Naqshbandi teachings. The reason is that Hazrat Gijduvani and Bahauddin Naqshband created the teaching that is expressed in the following eleven verses.

1. "Hush, I will give you a gift." According to mystical teachings, the universe is divided into two: mortal and eternal worlds. This world is the mortal world. A person will have to enjoy every moment of this world in limited quantities.

2. The rule "step by step" states that you need to control every step in a person's life. This rule is aimed at self-knowledge, self-management. At the same time, you need to control every step, every word and every deed. Everyone's self-control leads him to perfection, to Truth.

3. "Travel to the Homeland". There is a man, he is a tourist. His mind is a tourist, his body is a tourist. The highest journey in Islam is the path to the Path of Truth. The highest journey in life is Hajj. In mysticism, the main feature of the dervish-calenders was to travel and live. This order is also reflected in the template.

4. "Khilvat dar anjuman". Its simple expression means loneliness in society. When the Prophet (peace and blessings be upon him) was asked: "What is your sect based on?" This sentence is a logical interpretation of a "closed, narrow assembly".

5. "Yodkard" is a linguistic or heart dhikr, as stated in Rashakhot [31, p. 39]. Three statuses following the memorization rule supplement the content of the previous provisions. The meaning of Yodkard is that the Sufis in the sect should always live with the remembrance of the Truth in the mortal world.

6. "Bozgasht" is the mortal life of man, from which he will return to the eternal world.

7. "Guardian" means to warn yourself against any evil Satanic ways.

8. "Remembrance" means to be alert, always remembering Subhanaha wa Taala with pleasure.

It is known that the Rashis founded by Bahauddin Naqshband himself are of particular importance in the Naqshbandi sect. There are three of them, and they make up the 9th, 10th and 11th branches of the sect:

9. "Vukufi zamoniy" means that a Sufi spends every minute and second of his life to thank Allah and do only good to His servants.

10. "Vukufi adadiy" means to note that in the process of dhikr, order and number have a special place. ".. It consists in following the number in dhikr" [31, p. 39]. He teaches that one should know the holy prayers, words and follow them.

11. "Vukufi kalbiy" - this means that the heart of a Sufi should be dhikr. 
One who perfectly follows the above eleven sacred rules will attain the level of a perfect human being.

In the treatises of Sheikh Aziziddin Nasafi "The ideal man", "The goal of the axis", "Zubdatul hakoyik" and others, the problem of the ideal man is considered somewhat differently. In it, this concept is considered in connection with the emergence, development and career of a person. As a result, in the descriptions of Aziziddin, we see the characteristics and moral qualities of a real person. It should also be noted that Nasafi confuses the views and attitudes of some sciences in Islam to man and teaches and studies man as a heavenly being and the creation of the earth. In Nasafiyah, the ideal man is closely related to the concept of the soul. Human careers are considered spiritual. This is how burnout occurs from general concepts to thematic ones. Another reason for this is Aziziddin Nasafi's understanding of perfection based on the theory of ascension and ascension. This theory is related to the concepts of large and small world respectively. This is because Nasafi joined Ibn Arabi and called man the world of sagira (small world), the divine world and the material world together - the world of the grave (great world). Thus, the human universe is a miniature copy of the grave.

Aziz al-Nasafi describes the ideal person as follows: words, good deeds, good morals and education.

The first three qualities listed by Nasafiy, namely kind words, good deeds and good manners, are taken from the Zoroastrian book Avesto (Guftori nek, kirdori nek, Yu raftori nek). A person endowed with these qualities refrains from lies, hypocrisy and evil and is always ready to do good deeds with good intentions. Aziziddin Nasafi added the word "education", that is, the demand for mystical purification, to the word of Zoroaster about good morality. According to him, the task of the righteous who embarked on the path of the sect is to acquire these four qualities. One who "perfects these qualities in himself, attains perfection."

From this definition of nasafi, two conclusions can be drawn. First, from the point of view of a scientist, the ideal man is not an abstract being, different from life, but a real man. A person with good qualities can rise to such a career. The second conclusion is that, according to Nasafi, the rank of the perfect person is the highest rank that can be achieved through the teachings and teachings of Islam.

The model proposed by the famous philosopher, academician Erkin Yusupov takes into account the following aspects of national education:

- the formation of high moral qualities in public education; 
- teaching young people national heritage and values;

- the formation of the human factor;

- teaching people to work honestly, entrepreneurship and entrepreneurship;

- instilling a sense of national pride in young people;

- Ensuring the continuity of training and education.

According to the scientist, these features of national education can be combined with the modern education system, and also have a positive effect only if they are associated with our national traditions and values.

E. Yusupov concludes that the problems of education are more important than the system of ideas and ideologies in all periods of human history. The struggle for human consciousness and faith also manifests itself in the form of influencing young people through educational means. Therefore, the upbringing of a physically healthy, spiritually mature person remains one of the basic principles of the ideology of the national independence of Uzbekistan [40, p.18].

\section{THEORETICAL BACKGROUND.}

After all, the main goal of the national model is to educate an ideal person.

In our opinion, an ideal person cannot be formed without the requirements of both modern and traditional education.

Indeed, the experience of developed countries in the field of education is based on advanced pedagogical technologies. These best practices also address the immense challenges of meeting the interests and educational needs of learners.

A free civil society can only be built by spiritually mature people who lively believe in noble ideas. Therefore, in our renewed society, special attention is paid to the upbringing of a healthy generation, youth, the formation of a free civic spirit, the development of harmoniously developed people through a high level of spiritual and educational work. In our country, the expansion of the movement of a healthy generation, a radical reform of the education system based on the national curriculum are also important steps towards the realization of this glorious goal.

An effective factor in the comprehensive education of young people is the effective organization of their leisure time. However, it should be noted that today our young people do not go to libraries, do not spend their free time in cultural institutions, do not engage in independent reading. Organize leisure cultural events for young people: youth, women's organizations, educational institutions, district officials, republican and local trade unions to organize trips to cultural sites, 
historical monuments in the cities of the republic, short-term recreation programs in the development of sanatoriums. and implementation, you should pay attention to the holding of celebrations in the form of festivals in every district, every microdistrict. The role of 5 important initiatives is also invaluable.

According to Islam, man is the ruler and flower of the universe, and horses on land, ships in the sea and everything on earth and in the sky obey him. Everything that exists in the world was created for man, for his prosperity, for his happiness. A person should be grateful for this and live in this world. This is stated in the Surat al-Bakara: He made the earth a foundation for you, and the sky - a building, and sent down water from the sky, and produced fruits for you as food. So don't tune your rivals into Allah while you know. [38]. Therefore, in addition to prayer, a person should do good deeds in this world, do good deeds, help others, especially those in need and the poor, give them alms and be merciful.

In Islam, much attention is paid to such humane qualities as generosity, mercy, generosity and kindness. In particular, several suras of the Qur'an mention the performance of good deeds for orphans, widows, the poor, the needy and needy. "Do good to your parents! Also to relatives, orphans, poor people, relatives and strangers' neighbors, your companion next to you, a passenger (stranger) and a slave (dependent) under your command (do good)! Indeed, Allah does not love arrogant and boastful people "[38].

Sheikh Abdul Qadir Gilani's views on an ideal man are described in his Devoni Gavsul Azam, Maktuboti Jilani, Tuhfatul Qadiriya, Sirrul Asror. Maktubot "and" Kasidai Gavsia ".

Gilani also calls the ideal man by the name of a real man [41, 17]. In his opinion,

The ideal man is one whose spirit has been lifted to the highest level.

The ideal man is a man of poverty.

The ideal man is one who restrains his desires.

The ideal man is one who is in harmony with body and soul.

The ideal man is one who understands the truth.

The ideal man is a man of light.

A perfect man is a person with divine knowledge [26, p. 118-119].

Thus, a tax on excellence should have the 7 qualities listed above. Gilani analyzes each quality and describes them.

The first is a person whose spirit has risen to a higher level. He says: "Allah created a human soul from the spirit of the Prophet Muhammad (peace and blessings 
of Allah be upon him) in the world of Lohuti (that is, divine) and in the true ahsan calendar (in the most beautiful way)" [32, p. 97]. In other words, the human soul had to rise to the level of the Lohut world and possess the qualities of the Prophet Muhammad.

The second is a person with a poverty status. Its essence is that Gilani does not mean the poor and needy, but a person who does not hide his wealth from others, who is generous and merciful in the path of Allah. Here the owner of property and wealth is not condemned, but it is understood that they should not be transferred to property, not attached to it. It is generally accepted that the wealth given by Allah should be spent on those in need.

The third is a person whose body and soul are in harmony. Gilani emphasizes here that the body cannot be without the soul, the spirit without the body, and says that without one of them a person cannot function. Only when body and soul act in the same and harmonious manner can a person achieve perfection, "when body and soul are in harmony, a person becomes perfect. Just as the body is necessary for the perfection of the soul, so for the perfection of the body, the soul must strive for it, not forgetting about its origin. A person degrades only if he is surrendered to bodily desires, and as a result he cannot reach the level of an ordinary human being, let alone correspond to the great title of a perfect human being "[26, p. 120-121].

The fourth is the one who restrains his desires. Lust is an important aspect of mysticism. After all, a tax that cannot control its desires cannot rise to the level of the ideal person or guardian. Gilani compares lust to happiness and unhappiness. When a person succumbs to lust, he is unhappy, and conversely, when he restrains his lust, he is happy. In this regard, Gilani says: "When sincerity and kindness prevail in a person, that is, when his feelings become priesthood, his complacency with bliss turns into bliss. If a person is overcome by bad desires, the opposite of what we talked about above, then the side of complacency will prevail over happiness "[32, p. 93].

The fifth is a person who understands the truth. A person achieves this not with external knowledge, but with internal knowledge, not with his mind, but with his heart.

The sixth is a man of light. Gilani calls those who manifest divine light enlightened people. People who embody the light of the Prophet Muhammad are real people.

Seventh, a person who has mastered the science of Ladun can be a perfect person. But the Sufi emphasizes that only divine knowledge is lacking in order to achieve 
human perfection. Both external and internal sciences should not be neglected, and the need for both emotional and mental, internal and irrational knowledge should not be forgotten. Gilani believed that the acquisition of knowledge, enlightenment, morality, physical and spiritual education, the development of a person in the spirit of love for God and his education in the spirit of awareness were the main means leading a person to perfection.

Thus, according to Gilani, "a perfect man is a great, blessed, radiant, virtuous and blessed being who possesses the knowledge of truth, whose soul is holy, who manifests the divine, who enjoys the mind, whose soul is perfect to the level of the Lohut world, and who attains states of poverty "[26, 123-б.].

\section{RESULTS.}

Summarizing the above ideas about the ideal man, we come to the following conclusions:

- The ideal man is the most perfect, wisest and wisest of men.

- An ideal man is a mediator between Ilox and people, a great patron who conveys a divine command, the secret of the invisible to ordinary people.

- In the career of an ideal person, the mind is a slave (the mind is equal to the first. First, Allah created the slave of the mind, that is, the Perfect Man, and then because of him other creatures were created.

- The soul of an ideal person has long been known, it is the most powerful spirit created by God.

- The ideal man is a noble person who grew out of human society. He was not a spirit whose career was clear from the very beginning, but which matured in the process of moral purification.

"Therefore, every person with pure morality and dedication can strive for excellence and get their share along the way.

- The highest sign of perfection is to follow the path of truth and benefit people. The more a person benefits people with his words, deeds and intentions, the more he guides the wicked and the more he sacrifices on the path of Truth, the more perfect he is.

As a result of studying and analyzing the idea of an ideal man, the following conclusions were made: 
- The idea of an ideal man is a priority idea and principle of our national ideology, which plays an important role in getting rid of the ideology of the dictatorial regime, in improving the national idea.

"Alisher Navoi not only expressed his views and valuable ideas about the ideal person in his works, immortal epics, gazelles and rubai, but also earned the title of a great poet-humanist, an example for all mankind. He always shared the concerns of ordinary people, sponsored them. These circumstances show that Alisher Navoi has a practical approach to the idea of an ideal man.

\section{CONCLUSION.}

If you call this great man a saint, then he is a saint of saints, a thinker, a thinker of thinkers, a poet, a sultan of poets "[19, p. 47]. Indeed, the immortal ideas of the great poet about the perfect man, his wise thoughts are an important basis for the rise of our society, for the education of young people as harmoniously developed people.

- The idea of an ideal person in the Middle Ages played an important role not only in education, but also in the development of countries and the spirituality of peoples. The eternal works of the great scientist, expressing the idea of a perfect person, in recent years have played an important role in the humanization of the people of Movarounnahr and Khorasan, instilling universal values in their way of life and consciousness.

- As Islam Karimov noted, "a poet who, as deeply as Navoi, expresses the joys and sorrows of the human heart, kindness and the meaning of life, is rarely found in the history of world literature. Love for the native language, a sense of understanding of its incomparable wealth and greatness also entered our minds and hearts, first of all, with the works of Navoi. The more we enjoy this priceless heritage of our people, the more it will become a powerful enlightening weapon in raising our national spirituality, in improving the noble human qualities in our society "[19, p. 49-48].

- An ideal person is a just, wise, courageous, selfless, generous person who combines such human qualities as patriotism, nationalism, humanity, justice, tolerance, courage, hard work, sweetness, loyalty, patience.

"The views of Eastern thinkers on the ideal man play an important role in educating the youth of our society as a harmoniously developed generation, in understanding its essence. 


\section{REFERENCES:}

1. Abdullaev A. Naqshband in the interpretation of Navoi // Communication. -Tashkent, 2005. -№ 1. -B. 31-36.

2. Abu Nasr Farubi. About virtue, happiness and perfection. - Tashkent: Writer, 2002.

3. Abu Nasr Farubi. The city of noble people. - Tashkent, Abdullah Kodiri National Heritage Publishing House, 1993.

4. Abdukodirov A. Navoi and mysticism // Literary heritage. - Tashkent, 1991.

5. Alisher Navoi. Mahbub ul-kulub. MAT. T. 14. - Tashkent: Fan, 1998.

6. Alisher Navoi. Nasoimul-muhabbat. MAT. T. 17. - Tashkent: Fan, 2001.

7. Alisher Navoi. Moonshaot. MAT. T. 14. - Tashkent: Fan, 1998.

8. Alikulov X. Socio-utopian ideas in Central Asia. -Tashkent: Fan, 1983.

9. Aripov M. Humanism of Alisher Navoi. -Tashkent: Uzbekistan, 1991.

10. Bertels E. Navoi and Jami. Fav. Trudy. -M .: Science, 1965.

11. Ibrahim Hakkul. The theme of the perfect man in the poetry of Navoi // Creative heritage of Alisher Navoi and its world significance. - Tashkent-Navoi: Science, 2001.

12. Ibrahim Hakkul. Return to Navoi. -Tashkent: Fan, 2007.

13. Jamiy - the ideal man in the Navoi ideal // Jamiy and Uzbek literature. -Tashkent: Movarounnahr, 2005.

14. Jumaboev Y. From the history of the development of philosophy and moral thought in Uzbekistan. - Tashkent: Teacher, 1997; Abdukodirov A. Navoi and mysticism // Literary heritage. Tashkent, 1991.

15. Zhoraev N. "Agar ogoks sen ..." - Tashkent, "The Writer" 1998.

16. Zakhidov V. The world of ideas and images of Alisher Navoi. - Tashkent: From thin. literature of the Uzbek SSR, 1961.

17. Zokhidov A. The meaning of Alisher Navoi's views on the ideal man in our time // Social sciences in Uzbekistan. -Tashkent: 1991. -№11.

18. Karimov I. There is no future without historical memory. -Tashkent: Shark, 1998.

19. Karimov I.A. High spirituality is an invincible force. - Tashkent: Manaviyat, 2008.

20. Komilov N. Sufism. -Tashkent: Movarounnahr-Uzbekistan, 2009.

21. Four brochures about the ideal man. Translated by N. Kamilov. -Tashkent: Manaviyat, 1997.

22. Mallaev N.M. History of Uzbek literature. - Tashkent: Teacher, 1965.

23. Mahmoud Asad Joshon. Mysticism and beauty. -Tashkent: Adolat, 2004.

24. Mukhiddinov M. The ideal man - the ideal of literature. -Tashkent: Manaviyat, 2005.

25. Muminov I. Outstanding thinkers of Central Asia. -M.: Knowledge, 1966.

26. Navruzova G.N., Zoirov E.Kh., Yunusova G.S. In mysticism, man and the question of his perfection. - Tashkent, 2006.

27. Ochilov E. Two ways to perfection // Creative world of Navoi. -Tashkent: Fan, 2001.

28. Sultanmurod Olim. Naqshband and Navoi. - Tashkent: Teacher, 1996.

29. Sirojiddinov Sh. Navoi about spiritual maturity // Lessons of Imam al-Bukhari. -Tashkent, 2004. -№ 1. -B. 26-28.

30. The heart of the great poet's creativity. - Tashkent: Uzbekistan, 1970.

ISSN: 0010-8189

(C) CONVERTER 2021

www.converter-magazine.info 
31. Fakhruddin Ali Safiy. Rashacht. (Water drops) .- T.: Medical Publishing House of Ali Abu ibn Sina, 2003.

32. Sheikh Sayyid Abdulkadir Gilloni. Sirrul Asror. Maktubot. Translator O. Jo'raboev. - Tashkent, Movarounnahr, 2005.

33. Khairullaev M.M. To the study of the ideological origins of Navoi's worldview // Navoi and questions of literary influence. -Tashkent: Fan, 1968.

34. Khairullaev M. Early Renaissance Culture in Central Asia. -Tashkent: Fan, 1994.

35. Xondamir. Makorim ul-ahlak. - Tashkent: Publishing house of fiction Gafur Gulom, 1967.

36. From the history of socio-philosophical thought in Uzbekistan. - Tashkent: Uzbekistan, 1995; Important stages in the history of socio-ethical and humanistic thought in Uzbekistan. - Tashkent: Philosophy and Law, 2007.

37. Translation of the meanings of the Quran. Sura Al-Isra - Tashkent, TIU. 2001.

38. Translation of the meanings of the Quran. Sura Nisa. - Tashkent, TIU, 2001.

39. Ethical views of the thinkers of Central Asia and Khorasan. -Tashkent: Fan, 1992.

40. Yusupov E., Yusupov O. Family is the source of spirituality. - Tashkent, 2003.

41. Yunusova G. The teachings of Kadiri and its social and moral significance. False. fanl. nomz. power. written diss to get. author. - Tashkent, 2006, p. 17.

42. Rosenthal E. Some aspects of islamic political thought // Islamic culture. -An English Quarterly, 1948, january. -P. 6. 